\title{
Tectonics and Metallogeny of the Alpine-Himalayan Belt in the Mediterranean Area and Western Asia
}

\author{
by Slobodan Janković and Walther E. Petrascheck
}

The widespread acceptance of plate tectonics has led to many attempts to model metallogeny in terms of plate evolution. However, few syntheses have yet been produced on the Tethyan-Himalayan belt. This is partly because of the compexity of this collision zone when compared, for example, to the Pacific rim, and partly because of the sheer extent of the region. In this review the authors who have long studied the eastern Mediterranean and western Asia, summarize some of the recent work, especially under the framework of IGCP, and provide a guide to the major mineral districts. (Ed.)

\section{Introduction}

In the past 18 years, since the second author made a first attempt to reconcile some aspects of global tectonics with regional metallogeny (Petrascheck, 1968), many publications on this topic have appeared, filling altogether some metres in a book shelf. However, even the comprehensive books by Mitchell and Garson (1981) and Sawkins (1984) on metallogeny and plate tectonics provide little on the TethyanHimalayan Belt, though this has been for a long time the object of geological research. Now several major books have been published (e.g. Janković, 1977, 1987; Petrascheck and Jankovic, 1986) summarizing some of the results of two IGCP projects; number 3 ("Ore Provinces Separated by Continental Drift"), which ran from 1974 to 1978 under the leadership of W.E. Petrascheck, and number 169 ("Geotectonic Evolution and Metallogeny in the Eastern Mediterranean and Western Asia"), which extended from 1979 to 1985 under the leadership of Petrascheck and S. Janković.

The aim of Project 169, in which 10 countries were involved (Algeria, Austria, Bulgaria, France, Greece, Italy, Romania, Soviet Union, Tunisia, Yugoslavia), was to advance understanding of the metallogenic evolution of the region with special regard to plate tectonics. The study of the 7,000 $\mathrm{km}$-long belt stretching between Algeria and Afghanistan resulted in the recognition of surprisingly similar patterns of tectono-metallogenic evolution, particularly if one considers the Neo-Tethys in the sense of Şengör (1985).

Crustal extension began in this region during the Permian, leading to the formation of rift zones during Triassic time with their typical association of $\mathrm{Pb}-\mathrm{Zn}-\mathrm{Ba}$ deposits, preferentially along plate sutures. Ocean-floor spreading took place in some of the suture zones, during Jurassic and Early Cretaceous times, resulting in the emplacement of ophiolitic sequences, which are bearers of the rich chromium deposits in the Balkans, in Anatolia and Iran. The subsequent, partly Laramide, partly Tertiary, collisions and subductions produced granitoid magmas containing porphyry copper deposits such as the well-known ones of Bor, Sar Chesmeh, and Chagai Hills. Late tectonic compression caused the thickening of the continental crust, anatexis and related mineralization.

Special consequences of plate movements can only be identified where metallogenic units have been separated and displaced. In the Mediterranean such a phenomenon was shown for the first time by Agard and Emberger (1976), who correlated ore districts in southern Spain and Moroceo, and correlations between the $\mathrm{Pb}-\mathrm{Zn}$ and siderite districts of Sardinia and southern France were recognized by Zuffardi (1978).

In general, however, the rearrangement of continental fragments within the Tethyan Belt is complex, and neither their original position nor the rotations of the terranes that separated from the Eurasian and African plates are well known. Various models, some contradictory, are discussed in the comprehensive review of the evolution of the Mediterranean by Dixon and Robertson (1984).

\section{Regional Setting}

To the east of Dobrogea we can distinguish an older northern trough, the Palaeo-Tethys, which closed during Late Jurassic time to form the Cimmeride orogen, and a more southern trough, the Neo-Tethys, from which during Cretaceous-Tertiary time the Alpidic orogen emerged (Fig. 1, and see Şengör, 1985). Thus, it can be said that the basement of the different metallogenic zones at certain times belonged to Eurasia, at others to Gondwana. Accordingly, the pre-Mesozoic mineral deposits in the area bordering Tethys can be compared but not spatially correlated.

For example, apart from the Pelagonian-Apulian block (Fig. 1) the metamorphic massifs of southeastern Europe belonged to the Cimmerian Plate during the PalaeoTethyan period, but to Europe in Neo-Tethyan time. These fragments, like the adjacent Ukrainian Plate, are particularly rich in stratiform $\mathrm{Fe}$ and $\mathrm{Mn}$ deposits of Palaeozoic and older age. Likewise, the Pelagonian-Apulian block, consisting of the crystalline basement of the Inner Dinarides, the Adriatic Sea and Italy, and which sometimes is called the "African Promontory," bears abundant $\mathrm{Pb}$ and $\mathrm{Zn}$ deposits. The changing interrelations of these blocks are illustrated in Dixon and Robertson (1984).

Within the Alpidic provinces of the whole MediterraneanEurasian orogen, we can distinguish five groups of metallogenic zones and districts, which are related to the successive stages of tectonic evolution shown on Figure l: 


\section{METALLOGENIC ZONES}

Felated to late orogenic activation

[- Related to subduction and collision

Related to ocean floor spreading

Uा: Related to rifting

Related to alpidic remobilization

\section{SUTURE ZONES}

Suture of Neo-Tethys

Suture of Palaeo-Tethys

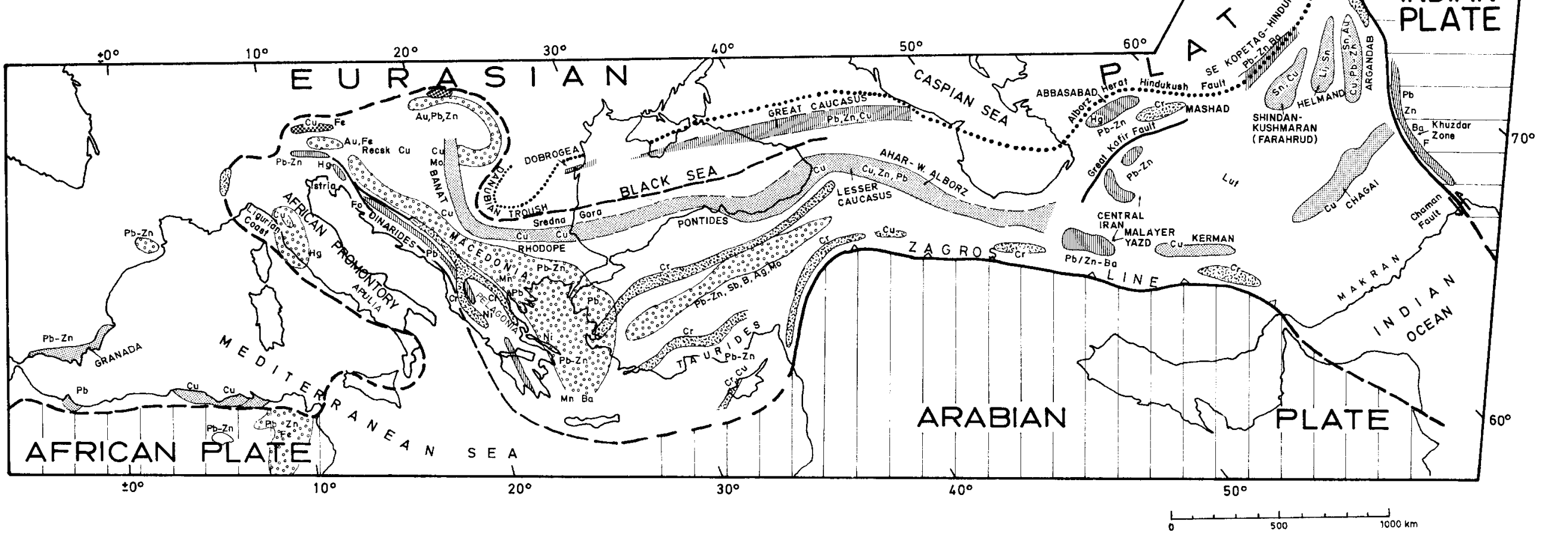

Figure 1: Generalized map of the metallogenic

zones in the Mediterranean-Himalayan belt. 
crustal attenuation (rifting, sensu lato, 260-240 Ma), ocean spreading (150-120 Ma), subduction and connected mountain building (110-60 Ma), continental collision, and late orogenic activity $(30-5 \mathrm{Ma})$.

The comparatively small ore zones related to Alpidic remobilization are characterized by deposits consisting of an originally Palaeozoic metal "stock," transformed and mobilized by the Alpidic metamorphism (Grauwackenzone in the Eastern Alps and Gemerides in the Western Car pathians), and it is quite possible that similar zones exist elsewhere in the belt.

\section{The Western Mediterranean Region}

During the Permian, extensional movements took place in the western part of the Circum-Mediterranean area, related to the eruption of large porphyries in the southwestern Alps, and to a minor extent also in Moroceo and in the Sierra Nevada of southern Spain. With this magmatism frequent deposits of $\mathrm{Ba}, \mathrm{Pb}-\mathrm{Zn}$ and $\mathrm{U}$ are associated, though the age of many is uncertain. In Early Triassic time, a shallow epicontinental sea advanced from the east, to cover the eroded Hercynian mountains of western Europe and northern Africa; widespread evaporite deposits resulted (Busson, 1982). Tensional tectonics continued throughout the Triassic, affecting the platform.

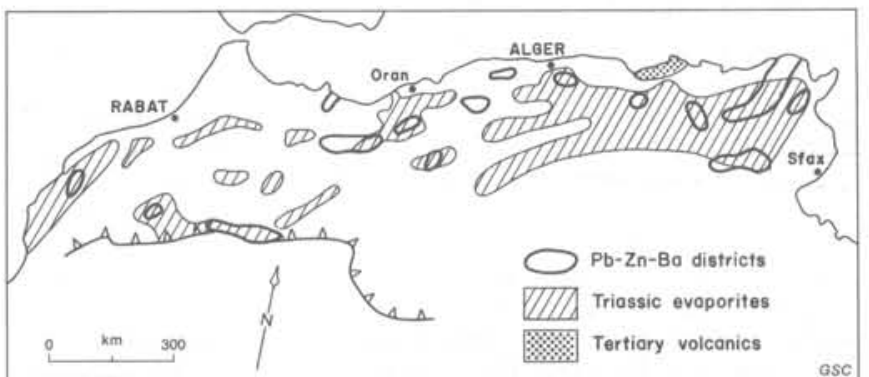

Figure 2: Distribution of evaporites and $\mathrm{Pb}-\mathrm{Zn}-\mathrm{Ba}$ districts in North Africa.

Ocean spreading began during the Late Jurassic and lasted until the Early Cretaceous. Formed during this period were the Ligurian and Tuscan ophiolites, which are remarkably poor in metal deposits compared with their eastern Mediter ranean equivalents. The historically famous, but economically less important, pyrite and copper deposits of Montecattini in Tuscany should be mentioned here. Sedimentary or volcano-sedimentary deposits of $\mathrm{Mn}$ with $\mathrm{Ba}$, hosted in Jurassic and Cenomanian limestones, can perhaps be considered as remote and delayed results of the ophiolitic magmatism.

The phases of Alpidic compression started during Late Cretaceous time and terminated during the Late Miocene (Zuffardi in Petrascheck and Janković, 1986). Deep reaching subduction did not, however, take place, and porphyry coppers are, therefore, missing. Ophiolites with their modest content of ores were obducted along the Ligurian coast, but the main consequences of the collisional events were anatectic magmas, mostly andesites and a few granites, at the margins of the North African, the Iberian and the Apulian plates.

A great variety of ore deposits, some apparently connected with these magmatic rocks, were formed between the Maghreb (North Africa), the Betic Cordillera and Tuseany. These range from skarn ores to volcano-sedimentary ores, and replacement bodies and veins, most of Miocene age, but economically the North African ores are the most important. The genesis and the age of many of these deposits

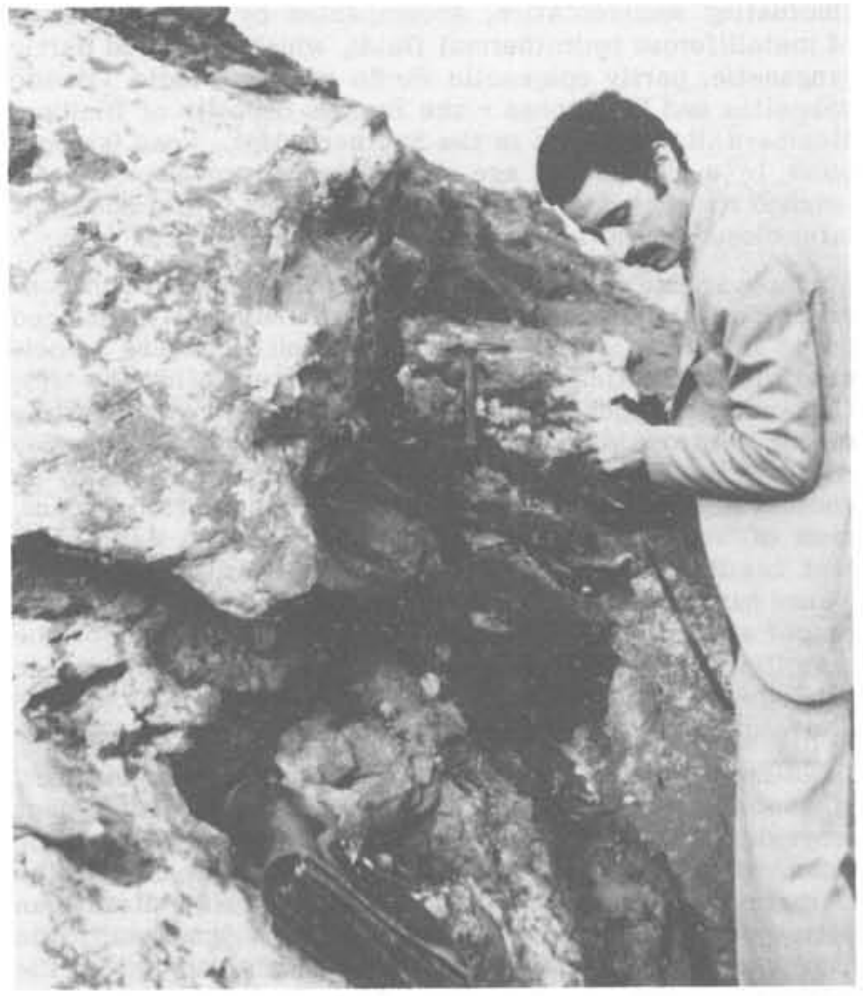

Figure 3: Algerian geologist Omar Kolli sampling calcite-quartz-tetrahedrite veins within oxidized siderite of the Ouenza iron mine, Algeria. Photo by W. Pohl.

have long been disputed, but Fuchs (in Petrascheck and Jankovice, 1986) favours a multiphase formation with a final supergene enrichment.

There may be a connection between the $\mathrm{Pb}-\mathrm{Zn}-\mathrm{Ba}$ North African deposits and the Triassic evaporites mentioned above. The spatial distribution of these evaporites - mainly rock salt - coincides remarkably with that of the MesozoicTertiary $\mathrm{Pb}-\mathrm{Zn}$ districts (Fig. 2), in an association reminiscent of the capability of saline brines to dissolve and re-precipitate metals. Rouvier and others (1985) have recently connected the $\mathrm{Pb}-\mathrm{Zn}$ and siderite deposits (Fig. 3) with salt-bearing diapirs, referring to previous statements by Sainfield (1952). This genetic model has been discussed in detail by Pohl and others (1986).

The second author believes that the problem should not be confined to diapirs, but that the deposits should be studied in a broader sense, together with the multiphase tectonics and the geothermal conditions existing during the MesozoicTertiary interval. Moreover there is the serious objection, also stated by Rouvier, that so many salt diapirs the world over are not surrounded by a halo of ore occurrences. An influence, at least indirectly, by Tertiary magmatism seems likely. In general, we can summarize all these deposits as related to late-collisional crustal activity.

\section{The Central Circum-Mediterranean}

The Alps and the Western Carpathians constitute the central section of the Circum-Mediterranean Belt. The northwards directed arc of the mountain belt is caused by the AdriaticApulian promontory (Fig. 4), which is a part of Africa or of a mid-Mediterranean microcontinent, according to Tollmann (1978). Rifting in the Alpine sector began during the Middle Triassic, when, at the border between the Northern and the Southern Alps, the Alpine-Dinaric "Cicatrice" (suture) developed. This was a zone of submarine faulting and 
fluctuating sedimentation, accompanied by the outpouring of metalliferous hydrothermal fluids, which deposited partly syngenetic, partly epigenetic $\mathrm{Pb}-\mathrm{Zn}$ ores in Middle Triassic dolomites and limestones - the famous deposits of Bleiberg Mezica-Raibl-Salafossa in the Southern Alps. Lead isotopes point to a Palaeozoic age, indicating a provenance from leached rocks at depth (Köppel, 1983). This suture zone was later closed by the Alpine compressional orogenesis.

The appearance of the Penninic troughs of the Alps in connection with the opening of the North Atlantic introduced ocean floor deposits in the Alpine realm; these are associated with insignificant occurrences of $\mathrm{Cu}$ and $\mathrm{Mn}$. The MidCretaceous-to-Eocene subduction led to the over-thrusting of the Austro-Alpine nappes (e.g. Funk et al., 1987). The Alps and the Carpathians are in general characterized by an unusual accumulation of extremely far-transported nappes, most of "African" origin. The thickening of the sialic crust that resulted from the flat-lying disposition of the thrust planes has prevented the rise of alpidic magmas or porphyry copper stocks. This is probably the ultimate reason for the scarcity of young alpidic magmatogenic deposits within the axial parts of the Alps and the Western Carpathians (Petrascheck, 1983).

Some small granite intrusions of $110 \mathrm{Ma}$ do occur, however, in the central Slovak Carpathians, caused by the giant orogenic movements of Late Cretaceous and Palaeocene time. Some of the siderite and copper deposits in the Carpathians are post-Triassic (alpidic), others are Hercynian (Ilavsky, 1979), but there is disagreement concerning the degree of remobilization involved. The same applies to the siderite deposits of the Eastern Alps, where both pre- and post-Triassic mineralization has been recognized. In some cases these deposits can be identified as of Late Cretaceous age.

In the inner side of the arc where the crust is thin, for example in the marginal parts of the Pannonian basin, abundant Tertiary volcanics and plutonic rocks occur in association with the rich gold and base metal districts of Slovakia and Transylvania. In the Carpathians of Romania several small rifts have yielded ore deposits.

The southern part of the central section is occupied by the Appenine peninsula (Zuffardi et al. in Petrascheck and Jankovic, 1986), where ocean-floor spreading took place in Jurassic time by separating Sardinia and Corsica from the mainland of Italy. Like those in the Alps, this oceanic trough was a comparatively small one, and the metallogenic fertility of its ophiolitic assemblage was low (Tuscany). Late Cretaceous bauxite was formed on the platform in Istria and in Apulia, but the main metallogenic epoch lasted from early Tertiary to Pliocene. The peri-Adriatic tonalites, as well as the granite of Elba, are products of the collision along the southern margin of Europe. Magmatic and post-volcanic activity here continues today, producing various deposits of $\mathrm{F}, \mathrm{Hg}$ and $\mathrm{B}$.

\section{The East Mediterranean Sector}

The Triassic Period was also a time of crustal tension in the eastern Mediterranean. Basaltic magma rose from the mantle and became contaminated by continental crustal material. The products were porphyrites and keratophyres, which were extruded into shallow intracontinental oceanic troughs (e.g. Fig. 5). Associated with these were the $\mathrm{Cu}-$ $\mathrm{Pb}-\mathrm{Mn}-\mathrm{Fe}-\mathrm{Hg}$ deposits of the volcano-sedimentary type in Montenegro, Bosnia and Slovenia, originating from the mantle (Jankoviē, 1977). A problem still to be investigated is whether the sequence of ore associations in all these deposits is comparable and whether it corresponds to distinct phases of rifting.

Jurassic time was a period of ocean-floor spreading; microoceans and micro-continents were formed. The Troodos Massif of Cyprus is regarded as obducted ocean floor from this time. Constantinou and Govett (1973) reported that nickel sulphide mineralization occurs here in the deeper harzburgite level, whereas the cupriferous layers and lenses are connected with the higher pillow lavas. Almost all the podiform chromite deposits in the eastern Mediterranean countries are situated in obducted ophiolites derived from an ancient oceanic realm. Ultramafic rocks that intruded into gneissic rocks of the continental crust are poor or devoid of chromium ore. The fact that the ophiolite assemblage in the eastern Mediterranean area is much richer in ore than is the western Mediterranean assemblage, may be explained by deeper crustal movements in the east.

The next major metallogenic epoch was at the CretaceousTertiary boundary. The formation of the large Eurasian copper belt took place at this time, extending from the Banat in southern Romania through northeastern Serbia, Sredna Gora, and northern Turkey to Armenia and Iran. Lenses of massive ore occur in Senonian andesite lavas, whereas disseminated copper ores are associated with Laramide $(60 \mathrm{Ma})$ intrusions. All compositions of magmatic rocks are present, particularly in the Banat and in Bulgaria. In deeper levels some metasomatic skarn deposits are known. The tectonic character of this magmatic-metallogenic zone is not clear, despite much investigation. For an assumed island-arc with back-arc rifting, the corresponding ocean is missing; it might have belonged to the hypothetical Danubian trough. This rift zone is a phenomenon that apparently does not match the classical model of plate tectonics, at least not in the European section. The associated ore deposits belong mainly to the subduction type.

Tertiary porphyry copper deposits not directly related to a subduction zone can be found in other areas of southeastern Europe (e.g. Recsk in northern Hungary, and Bucin and Skuries in Macedonia). These may be the result of mantle plumes. Later Tertiary metallogeny is related to intermediate and acidic magmatics. These comparatively rare plutonic rocks were formed at deeper levels than the associated volcanic rocks. However, a fundamental separation of plutonism and volcanism, as has been claimed by some authors, is not justified. This Neogene ore zone has several districts: the Western Carpathians $(\mathrm{Pb}, \mathrm{Zn}, \mathrm{Au}, \mathrm{Hg}$ vein deposits), the Transylvania Mountains ( $\mathrm{Au}, \mathrm{Ag}, \mathrm{Pb}-\mathrm{Zn}$ veins), the southern Serbian-Rhodopian district (veins and replacement deposits of $\mathrm{Pb}-\mathrm{Sn}-\mathrm{Sb})$ and the Aegean district (replacement deposits and impregnations of $\mathrm{Pb}, \mathrm{Zn}, \mathrm{Mn}, \mathrm{Ba}$ ).

The metallogenic zones of the Balkan Peninsula can be followed as far as Anatolia. As mentioned above, the Upper Cretaceous-Palaeocene copper belt of Banat-Sredna Gora

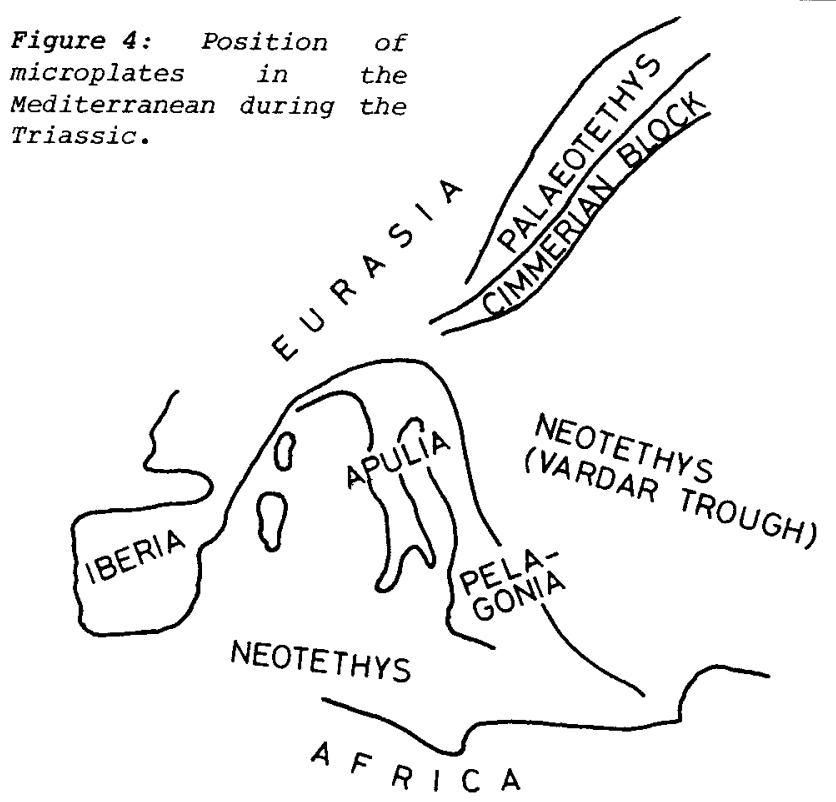


Figure 5: Section through the Brskovo deposit (Yugoslavia), a typical example of Triassic riftrelated ores. From Janković, 1987.

has its continuation in the Pontides, where the subduction related character of some of the deposits is clearer. A northern zone of ultramafics corresponds to the chromite deposits of Macedonia, whereas the southern Turkish zone with the famous, but now exhausted districts of Fethie and Guleman, is the continuation of the suture zone of Albania and central Greece. The widespread Neogene mineralization in western Anatolia and in the Taurides is characterized by replacement and vein deposits of $\mathrm{Pb}$,

$\mathrm{Zn}, \mathrm{Ag}, \mathrm{Ba}$ and $\mathrm{Mn}$. The frequency of $\mathrm{Ba}$ and $\mathrm{Mn}$ around the Aegean Sea may be connected with the start of early oceanization of this part of the crust in late Tertiary time.

In general, the southern branch of the orogen is much richer in $\mathrm{Pb}$ and $\mathrm{Zn}$ than is the northern branch (Petrascheck, 1976). As in the western Mediterranean region, $\mathrm{Pb}$ and $\mathrm{Zn}$ are situated near the northern edge of the ancient African Plate. It can be assumed that these metals were inherited from the underlying rocks. Tertiary rifting was not important for metallogeny in alpidic Europe - with the exception locally in Italy. The Jordan Graben in Syria and Palestine is only accompanied by traces of ore, in spite of underlying salt and remarkable heat flow:

Figure 1 shows the metallogenic zones of the TethyanHimalayan belt in relation to plate-tectonic features. These relationships have, however, been questioned by Routhier (1974) in a most stimulating critical review. Routhier emphasized the poor knowledge of plate boundaries in Mediterranean Europe, the controversial age determinations of deposits, and the definition of metallogenic units. The second author agrees with this assessment to some extent. Certainly well-established palinspastic maps of the area will have to be prepared before the ultimate correlation of ore districts can be envisages. Figure 1 can only be considered as a preliminary sketch.

\section{Western Asia: Regional Geotectonic Evolution}

The Alpine ore deposits and regional metallogenic units of western Asia are related to the realm between the Eurasian Plate in the north, and the Arabian and Indian plates in the south and southwest. This area shares some characteristics in common with other parts of the Tethyan-Eurasian metallogenic belt (Janković, 1984a). This western domain is the result of a very complex tectonic evolution connected with the history of Neotethys, its opening, development, island ares and microplates, and their welding, closing of ocean and subduction of oceanic crust (see Şengör, 1985, for a review).

From the late Precambrian until the late Palaeozoic southeastern Turkey, Iran, central Afghanistan and Arabia were part of one continent, a fragment of Gondwanaland, separated from the Eurasian Plate by the Hercynian "Palaeotethys" ocean. The tectonic development, as in the Mediterranean, commenced in Late Permian-Triassic time, by rifting along the Main Zagros fault, and spreading of the continental plate along the Zagros-Oman zone, resulting in the detachment of the Iran-Afghanistan microplate(s) from A rabia, and opening of a new ocean, "Neotethys."

The closing of Palaeotethys by the northward motion of the central Iranian-Afghanistan microplate(s) resulted in the latter becoming welded to the Eurasian Plate along a suture zone of oceanic crust. It is not yet certain whether the closing of the Palaeotethys by Late Triassic-Jurassic time was followed by subduction of these microplates beneath the Eurasian Plate. However, there were large areas of shallow sea and small Red Sea type oceanic basins, associated presumably with the fragmentation of continental crust during the period of movement of the continental mass from Arabia to Asia, but there are no reliable data on when and how these narrow oceanic basins were formed. Nevertheless, they are of particular importance for the recognition and delineation of microplate margins and metallogenic zones associated with them.

With the disappearance of the Palaeotethys ocean, the floor of the Neotethys began to subduct beneath southern central Iran and apparently disappeared by Late Cretaceous-Early Palaeocene time. By the end of the Mesozoic Era, all of the existing oceanic crust between Arabia and Asia here had been consumed along the Main Zagros Thrust Line (Stöcklin, 1977). The final closure took place in the Late Oligocene(?), when the Eurasian and Indian plates collided along the Indus Suture Zone.

The remnants of Neotethys are thus represented by narrow ophiolite scars that are thought to be relics of former oceanic crust. Partly covered by the Eocene flysch, they define the suture along which ancient continents or continental fragments were welded together. If these plate tectonic concepts are valid, and ophiolite zones with scars really do separate former continental margins, then in western Asia several ancient margins can be distinguished. These are the Main Zagros Thrust Line-Oman, the Chaman Fault (currently active plate boundary of the Indian Plate), and the Alborz-Herat Fault - Hindukush, marking the northern border of Stöcklin's "Central Domain"; its extension eastwards is conjectural. The Great Kafir Fault and others define the central Iranian (including Lut) - central Afghanistan microcontinent(s). Finally, there is Kohistan, which is a welded island are between the Indian and Eurasian plates, the junction being represented by the Main Mantle Thrust (Tahirkeli, 1979), which is part of the Indus-Zangbo (= Indus-Yarlung) Suture Zone.

Figure 1 includes a preliminary reconstruction of the borders of main microplates between two major conver gence zones within the area under consideration. These are the Alborz-Hindukush bordering the southern edge of the Eurasian Plate and the Zagros zone, formed at the southern edge of a complex of microcontinents, island arc and oceanfloored basins. This picture must be regarded as tentative, for the data are insufficient for a more detailed interpretation of the history of fragmentation, dispersion and reamalgation of the various fragments of Gondwanaland. The Alpine endogenous deposits of this western Asian region are thus associated with a variety of tectonic environments, 
most genetically related to specific volcanic and intrusive complexes, and a specific time interval (see Janković, 1987, for a general review).

\section{Mineralization Related to Intracontinental Rifting}

Following a relatively long period of quiet development during late Palaeozoic, widespread tectonic movements began by horizontal spreading and rifting during Late Triassic-Early Jurassic time. Ore deposits related to this tectonic setting are subdivided into two main groups; those in the central parts of spreading centers, and those associated with the flanks of graben-like basins and/or grabenhorst structures. The former group is genetically related to volcanic-intrusive and volcanic-sedimentary complexes. These include volcanic-sedimentary sulphides and oxides, with predominant $\mathrm{Pb}-\mathrm{Zn}$ accompanied by barite, $\mathrm{Fe}-\mathrm{Mn}$ oxide deposits, and sporadic skarn deposits. Massive sulphide deposits are both volcanic- and sediment-hosted, the latter usually associated with the more advanced stages of continental rifting - e.g. the Greater Caucasus.

The second group is related to shallow-water sediments, usually carbonate reef facies. These deposits are mainly non-magmatogenic, but volcanic sources can provide the necessary thermal energy to form and drive hydrothermal systems, mobilization of ore metals, and their transport to the site of deposition. One example would be the lateral movement of brines from the central part of the rift. Thermal energy can also derive from heat-fluxes originating from rifting processes.

These mineral deposits are predominantly low temperature, composed of $\mathrm{Pb}-\mathrm{Zn}$ sulphides, one of which usually dominates the other, plus local barite and sporadic fluorite. They are situated near continental margin such as the $\mathrm{Pb}-\mathrm{Zn}$ deposits of central Iran and the $\mathrm{Pb}-\mathrm{Zn}$-barite-fluorite deposits of Baluchistan.

\section{Mineralization Related to Ocean-Floor Spreading}

The deposits are numerous, particularly in central and southern Anatolia where they are a continuation of the Balkan Peninsula ophiolites, and farther along the Zagros zone of Iran and the Indus-Yarlung suture of western and northern Pakistan, Tibet and China. Two main groups of deposits can again be distinguished: magmatic deposits involving titaniferous magnetite, and podiform chromite, minor $\mathrm{Cu}-\mathrm{Ni}-\mathrm{Fe}$ sulphides in peridotite, and volcanosedimentary and volcanogenic deposits, including cupriferous pyrite deposits in Oman, and numerous, small, bedded ferro-manganese deposits. The most important chromite deposits are in Albania, southern Turkey and southeastern Iran.

\section{Mineralization in Subduction-Related Setting}

Along the southern margin of the Eurasian Plate, above the subducted Afro-Arabian and Indian plates, significant nonferrous hydrothermal deposits formed during Tertiary time, in close association with calc-alkaline and partly alkaline volcano-plutonic complexes.

Porphyry copper deposits are known in Iran (the most significant is Sar Chesmeh near Kerman), the Chagai district in Pakistan (e.g. Saindak), and the Yulong district in Tibet. Skarn deposits are numerous, but generally of little economic importance. There are, however, in Afghanistan and the southern Pamirs, scheelite and cassiterite deposits of considerable size, and chalcopyrite occurrences worthy of note. Greisen deposits are widespread in the ore fields of $\mathrm{SE}$ Afghanistan, where cassiterite is often accompanied by wolframite, and similar deposits are known in the southern Pamirs.

Volcanogenic hydrothermal deposits are mostly associated with calc-alkaline complexes. The mineralization is mainly located at subvolcanic levels, or in surrounding rocks, epigenetic with respect to volcanics. Replacement type deposits are also found. The massive $\mathrm{Cu}$ sulphide and $\mathrm{Pb}-\mathrm{Zn}$ sulphides are the most common representative of this type. The cassiterite mineralization in the Shindan-Kushamaran district of Afghanistan resembles porphyry tin mineralization in the Andes. Volcano-sedimentary deposits are mainly associated with island arcs and andesite-dacite ( \pm rhyolite) suites. The $\mathrm{Cu}$ and $\mathrm{Cu}-\mathrm{Zn}-\mathrm{Pb}$ sulphides predominate, accompanied by massive pyrite (e.g. massive sulphide deposits in the Pontides-Lesser Caucasus metallogenic zone).

Mineralization Related to Continent-Continent Collisions

These deposits are mostly developed in the zone of the collision between the Indian and Eurasian continents. The mineralization is associated mainly with granites derived from the continental crust (S-type granitoids). The most significant deposits discovered are in southeastern Afghanistan where very large spodumene deposits associated with pegmatite granites have been found recently (Janković, 1982).

\section{Summary}

Summarizing the genetically classified groups of mineral deposits described above and re-arranging them in a geographic sense, the following metallogenic districts can be distinguished. The Ahar-Western Alborz district contains a few skarn copper deposits (Mazraeh) and small $\mathrm{Pb}-\mathrm{Zn}$ veintype deposits related to Tertiary calc-alkaline complexes. The Abbasabad district comprises both podiform chromite and volcano-sedimentary massive copper sulphides and stratiform manganese deposits.

The Southern Kopet Dag-Hindukush metallogenic zone contains massive polymetallic volcano-sedimentary sulphides of Late Triassic age, Upper Cretaceous deposits associated with ophiolites, and Tertiary deposits related to volcanointrusive intermediate complexes. The latter include skarns, sporadic porphyry coppers and stratabound low-temperature $\mathrm{Pb}-\mathrm{Zn}-\mathrm{Ba}$ mineralization in carbonate rocks.

The Yazd-Malayer zone is characterized by numerous stratiform and vein-type $\mathrm{Pb}-\mathrm{Zn}$-barite mineralization in Cretaceous limestone, located along the continental margin of the west-central Iranian block (Jankovic, 1984b). The Kerman metallogenic zone contains very significant copper deposits, genetically associated with Neogene volcanoplutonic calc-alkaline complexes. They are grouped within a narrow elongated zone, subparallel to the boundary of continental margin.

The Chagai district is characterized by porphyry copper mineralization and occasional occurrences of massive sulphide and mineralized skarn. The Lut-Farahrud district contains Sn and $W$ deposits, some of them of economic importance (e.g. Vostok and Turmalin in Afghanistan). Small $\mathrm{Cu}$ and $\mathrm{Pb}-\mathrm{Zn}$ deposits are also found, as well as numerous occurrences of $\mathrm{Hg}$.

Finally, in the central Afghanistan range there are numerous deposits of economic importance $(\mathrm{Cu}, \mathrm{Sn}$, minor $\mathrm{Pb}-\mathrm{Zn}$, and $\mathrm{Au}$ are related to greisen, skarn and hydrothermal vein types). The pegmatites associated with Oligocene granite contain Li, Nb and Ta.

\section{Final Comment}

The synthesis presented in this review is based on the work of many scientists from different countries. It is not surprising, therefore, that their results are extremely varied in terms of subject, method, and scope of presentation. Some interpretations are based on plate tectonics, while others are related to geosynclinal evolution, and it is difficult to adjust the terminology used by some workers to that generally accepted in English-speaking countries. Despite these difficulties, IGCP Project 169 can be considered a significant contribution to the better understanding of the metallogeny of the Alpine-Himalayan belt. 
Nevertheless, most of the Tethyan reconstructions have been based on palaeomagnetic data, and the relations of the palaeofacies and palaeotectonics have not been sufficiently considered. A reliable reconstruction of the Mesozoic and the Tertiary Mediterranean will only be achieved after a synthesis of all these elements. It would, therefore, be most desirable if this key region for mobilistic tectonics remained in the focus of the IGCP.

Acknowledgements: The authors are grateful to Mrs. Alexandra Pärtan (shown also in the authors' photograph) for her assistance in the preparation of this review. Mrs. Pärtan has been Executive Secretary of the Austrian National Committee for IGCP since its establishment and has attended many IGCP Board meetings as an observer.

S. Janković (on left) teaches mineral exploration at the faculty of Mining and Geology, University of Belgrade (Dusina 7, 1000 Belgrade, Yugoslavia). In recent years he has worked extensively in Pakistan for the UNDP, enabling him to acquire a thorough knowledge of the mineral resources of this country, as well as of the metallogeny of Central Asia. Prof. Jankovic was co-leader of IGCP Project 169.

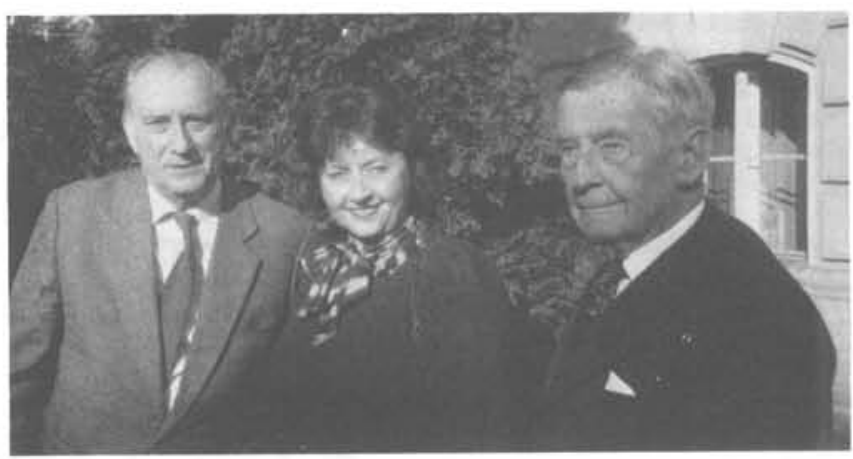

W.E. Petrascheck (on right) is Professor Emeritus for Economic Geology at the Mining University of Leoben, Austria, and is based now at the Austrian Academy of Sciences (Erdwissenschaftlicke Kommissionen, Osterr. Akad. der Wissenschaften, A-1010 Wien, Dr. Ignaz Seipel Pl. 2, Austria). He is the author of numerous works on coal and ore deposits and is especially interested in metallogenic provinces and maps. He is co-author of the International Metallogenic Map of Europe and the initiator of the Austrian National Committee for IGCP. He was leader of IGCP Project 3 and co-leader of Project 169.

\section{References}

Agard, J. and Emberger, A., 1976. Gites minéraux et tectonique globale. Bulletin du Bureau de Recherches Geologiques et Minieres, Deuxieme serie, Section II, no. 1 , p. 65 .

Böhmer, M., 1987. Tertiary metallogenic evolution in the West Carpathian volcanogenic ore deposits. In: S. Janković, 1987, Mineral Deposits.

Busson, G., 1982. Le Trias comme période salifère. Geologische Rundschau, v. 71 , no. 3 , p. $857-880$.

Constantinou, G. and Govett, G.J.S., 1973. Geology, geochemistry and genesis of Cyprus sulfide deposits. Economic Geology, v. 68, no. 6, p. 843-858.

Dewey, J.F., Pitman, W.C., Ryan, W.B.F. and Bonnin, J., 1973. Plate tectonies and the evolution of the Alpine system. Geological Society of America Bulletin, 84, no. 10, p. 3137-3180.

Dixon, J.E. and Robertson, A.H.F., 1984. The Geological Evolution of the Eastern Mediterranean. Geological Society Special Publication 17, Blackwell Scientific Publication, Oxford, 824p.

Funk, H. et al., 1987. The evolution of the northern margin of Tethys in eastern Switzerland. Episodes, v. 10, no. 2, p. 102-106.

Grubic, A., 1974. Eastern Serbia in the light of the new global tectonics; consequences of this model for the interpretation of the tectonics of the northern branch of the Alpides. In: Metallogeny and Concepts of the Geotectonic Development of Yugoslavia. Belgrade University, Belgrade, Yugoslavia, p. 179-211.

Ilavsky, J. and others, 1979. Métallogenèse de l'Europe Alpine Centrale et du Sud-Est. Bratislava, 413p.

Janković, S. (ed.), 1977. Metallogeny and Plate Tectonies in the Northeastern Mediterranean. Belgrade.

Janković, S., 1982. The Tethyan Eurasian metallogenic belt: Alpine metallogeny of the Karakorum-Southern Pamir-Hindu Kush sector and continuous regions. Mem. vol. Acad. V.I. Smirnov, Nauka, Moscow.

Janković, S., 1984a. Metallogeny of the Alpine granitoids in the TethyanEurasian metallogenic belt. - 27th International Geological Congress Proceedings, Metallogenesis and Ore Mineral Deposits. v. 12, p. 247-273.

Janković, S., 1984b. Stratabound low temperature $\mathrm{Pb}-\mathrm{Zn}-\mathrm{Ba}+$ or $-\mathrm{F}$ deposits in carbonate rocks of Western Asia: Geotectonic setting and main metallogenic features. In: Wanschkuhn, A., et al. (eds), Syngenesis and Epigenesis in the formation of Mineral Deposits. Springer Verlag, Heidelberg, F.R.G., p. 373-390.

Janković, S., 1987. Mineral deposits of the Tethyan Eurasian Metallogenic Belt between the Alps and the Pamirs. Faculty Mining and Geology, University of Belgrade.

Köppel, V., 1983. Summary of the lead isotope data from the ore deposits in the Eastern and Southern Alps: Some metallogenic and geotectonic implications. In: Schneider, H.J. (ed.), Mineral Deposits of the Alps and of the Alpine Epoch in Europe. Springer-Verlag, Heidelberg, p. 163-168.
Mitchell, A.H.G., Garson, M.S., 1981. Mineral deposits and global tectonies settings. Academic Press, London, $405 \mathrm{p}$.

Monseur, G., 1976. Mineralisations Siluro-Ordoviciennes d'Espagne. Schriftenreihe der Erdwissenschaftlichen Kommissionen Osterreichisehe Akademie der Wissenschaften, v. 3, p. 77-99.

Petrascheck, W.E., 1968. Kontinentalverschiebung und Erzprovinzen, Mineralium Deposita 3, no. 1, Berlin, p. 56-65.

Petrascheck, W.E., 1976. Mineral zoning and plate tectonics in the Alpine-Mediterranean area. In: Strong, D.F. (ed.) Metallogeny and Plate Tectonics. Geological Association of Canada, Special Paper 14, Waterloo.

Petrascheck, W.E. (ed.), 1983. Ore Mobilization in the Alps and in SE Europe. Schriftenreihe der Erdwissenschaftlichen Kommissionen Oster reichische Akademie der Wissenschaften, v. 6, 106p.

Petrascheck, W.E. and Janković, S. (eds.), 1986. Geotectonic Evolution and Metallogeny of the Mediterranean Area and Western Asia. Proceedings of the final Symposium of IGCP Project 169. Schriftenreihe der Erdwissenschaftlichen Kommissionen Osterreichische Akademie der Wissenschaften, Wein, v. 8,298 p.

Pohl, W., Amouri, M., Kolli, O., Scheffer, R. and Zachmann, O., 1986. A new genetic model for the North African metasomatic siderite deposits. Mineralium Deposita 21, no. 3, p. 228-233.

Rouvier, H., Perthuisot, V. and Mansouri, A., 1985. Pb-Zn deposits and salt-bearing diapirs in Southern Europe and North Africa. Economic Geology, v. 80 , no. 3 , p. 666-687.

Routhier, P., 1974. Review and critical comparison of data and approaches from an exploration geologist's point of view. Problems of Ore Deposits, Fourth IAGOD Symposium, v. II, Varna, p. 515-522.

Sainfeld, P., 1952. Les Gites plombo-zincifères de Tunisie. Annales des Mines et de Geologie Nr. 9, 285p. plus atlas.

Sawkins, F.J., 1984. Metal deposits in relation to plate tectonics. Springer-Verlag, Berlin: New York. 325p.

Şengör, A.M.C., 1985. The story of the Tethys - how many wives did Okeanos have? Episodes, v. 8, no. 1, p. 3-12.

Stöcklin, J., 1977. Structural correlation of the Alpine ranges between Iran and Central Asia. Société Géologique de France, Memoires hors serie, no. 8 , p. $333-353$.

Tollmann, A., 1976 (1978). Plattentektonische Fragen in den Ostalpen und der plattentektonische Mechanismus des mediterranen Orogens. Mitteilungen der Osterreichischen Geologischen Gesellschaft 69, p. 291- 351.

Zuffardi, P., 1978. Plate Tectonies and Ore Mineral Provinces in Western European Mediterranean Region. Schriftenreihe der Erdwissenschaftlichen Kommissionen der Osterreichische Akademie Wissenschaften, v. 3, p. 61-77, Vienna. 